\title{
PENGUATAN BUDAYA ORGANISASI MELALUI SISTEM PENGENDALIAN MANAJEMEN UNTUK MENINGKATKAN KINERJA HOTEL
}

\author{
Nerissa Arviana \\ Fransiskus Eduardus Daromes* \\ Kunradus Kampo \\ Universitas Atma Jaya Makassar, Jalan Tanjung Alang No. 23, Makassar \\ *fedaromes@gmail.com
}

\author{
A R T I C L E I N F O \\ Article history: \\ Received October 15, 2020 \\ Revised December 2, 2020 \\ Accepted December 8, 2020
}

Key words:

Organizational Culture, Management Control System, Hotel Performance

DOI:

https://doi.org/10.33508/jako.v13i1.2769

\begin{abstract}
A B S T R A C T
This study explains that management control system is a mechanism to encourage the strengthening of organizational culture in enhancing hotel performance. The study used a survey method through questionnaires on managers and heads of departments at 3, 4, and 5-star hotels Makassar. Data analysis was performed by path analysis and Sobel test. The results show that organizational culture has no direct effect on hotel performance, however, it has a positive and significant effect on the management control system, which in turn has a positive and significant effect on hotel performance. In other words, management control system mediates the influence of organizational culture on hotel performance.
\end{abstract}

\begin{abstract}
A B S T R A K
Penelitian ini menjelaskan bahwa sistem pengendalian manajemen merupakan sebuah mekanisme untuk mendorong penguatan budaya organisasi untuk meningkatkan kinerja hotel. Penelitian ini menggunakan metode survei melalui kuesioner pada manajer dan kepala departemen hotel berbintang 3, 4, dan 5 di Kota Makassar. Analisis data dilakukan dengan analisis jalur dan uji sobel. Hasil penelitian menunjukkan budaya organisasi tidak berpengaruh secara langsung terhadap kinerja hotel, namun demikian berpengaruh positif dan signifikan terhadap sistem pengendalian manajemen, yang selanjutnya berpengaruh positif dan signifikan terhadap kinerja hotel. Dengan kata lain, sistem pengendalian manajemen memediasi pengaruh budaya organisasi terhadap kinerja hotel.
\end{abstract}

\section{PENDAHULUAN}

Industri perhotelan merupakan salah satu sektor usaha dengan tingkat persaingan yang tinggi. Setiap hotel selalu bersaing dengan hotel lainnya dalam satu wilayah, baik secara langsung atupun tidak (Mitrović, Janković, dan Ivankovič, 2016). Oleh karena itu, salah satu cara yang dapat ditempuh hotel dalam menghadapi persaingan adalah dengan meningkatkan kinerjanya. Kinerja hotel mencerminkan prestasi yang dicapai hotel dalam memberikan pelayanan terbaik bagi para tamu. Pelanggan yang akan menggunakan jasa akomodasi biasanya memilih hotel yang memiliki kinerja baik. Dapat disimpulkan, jumlah kunjungan tamu hotel yang tinggi menunjukkan bahwa hotel tersebut memiliki kinerja perusahaan yang baik serta daya saing yang baik (Dewantara, Ali, dan Sudirman, 2010).
Ketua BPD Persatuan Hotel dan Restoran Indonesia (PHRI) Sulawesi Selatan, Anggiat Sinaga menyebutkan bahwa wilayah Sulawesi Selatan mengalami kelebihan pasokan kamar hotel berbintang dengan jumlah kamar mencapai 28.700 unit, dimana sebanyak 15.250 di antaranya berada di wilayah Makassar (Herlinda, 2019). Maraknya pembangunan hotel dan penambahan kamar ini menyebabkan terjadinya oversupply kamar yang memicu tingkat okupansi menjadi tidak maksimal. Sesuai dengan yang dikutip oleh Syamsi (2019), total okupansi hotel di Kota Makassar mengalami penurunan sekitar $36 \%$, dilihat dari semester pertama tahun 2018 dan 2019. Fenomena tersebut menggambarkan realita bahwa hotel perlu berbenah agar tetap mempertahankan kelangsungannya.

Fasilitas yang dimiliki hotel berbintang pada umumnya hampir sama, sehingga salah satu cara 
agar suatu hotel lebih unggul dari hotel lainnya adalah dengan mengedepankan intangible product yang dapat diperoleh melalui kualitas layanan yang lebih baik. Hal ini dapat didukung melalui budaya organisasi.

Hotel yang merupakan bisnis yang padat karya (labor intensive) harus mempekerjakan banyak orang untuk memenuhi kebutuhan tamu (Choi, Woods, dan Muramann, 2000). Dengan karyawan yang begitu banyak, tentunya mereka memiliki persepsi, latar belakang, dan sikap kerja yang berbeda-beda dan mereka harus bekerja sama tanpa adanya gangguan dari keberagaman tersebut. Budaya organisasi memiliki fungsi yang sangat penting dalam mengembangkan persyaratan untuk mengelola keberagaman (Clarke dan Iles, 2000). Secara umum, inilah mengapa budaya organisasi menjadi alat bagi organisasi untuk menyatukan berbagai keberagaman.

Setiap perusahaan pasti mempunyai budaya organisasi, baik dibuat (dikendalikan atau diarahkan) maupun tidak dibuat (dibiarkan untuk tumbuh liar). Budaya perusahaan yang dominan memiliki pengaruh kuat dalam membentuk anggota organisasi. Hal ini menyebabkan, budaya dapat mendukung keberhasilan implementasi strategi perusahaan. Budaya perusahaan dapat mengarahkan perilaku anggota organisasi untuk mencapai tujuan perusahaan dalam meningkatkan koordinasi serta pengendalian perusahaan (Hofstede dkk., 1990). Sistem Pengendalian Manajemen (SPM) didesain sebagai sistem yang memungkinkan pengendalian yang tepat sembari memfasilitasi budaya organisasi dalam mendukung keberhasilan implementasi strategi perusahaan.

SPM adalah langkah operasional yang dilakukan oleh manajemen untuk mendorong dan memastikan bahwa semua elemen dalam suatu perusahaan berusaha mencapai tujuan organisasi (Daromes, Ng, dan Kampo, 2018; Kampo, 2020). Sistem umpan balik dalam SPM, manajer mengukur kinerja, membandingkan pengukuran dengan rangkaian standar kinerja, dan, jika diperlukan melakukan tindakan koreksi (Merchant dan Van der Stede, 2018). Dengan demikian, penerapan sistem pengendalian manajemen mengonfirmasi apakah aktivitas perusahaan telah berjalan sesuai dengan yang diinginkan perusahaan serta apakah sistem tersebut telah berhasil membantu perusahaan mencapai tujuannya yang terkonfirmasi melalui hasil pengukuran kinerja.

Strategi perusahaan yang dibuat sebaikbaiknya, tidak akan bermanfaat bagi keberhasilan perusahaan bila tidak dikendalikan dengan baik.
Manusia yang memainkan peran dalam perusahaan. Peran sistem pengendalian manajemen dibutuhkan untuk mengendalikan orang-orang yang bekerja dalam perusahaan karena pada dasarnya mereka juga sosok individu yang bekerja dengan tujuan-tujuan pribadi mereka. Tujuan ini mungkin selaras dengan tujuan perusahaan, atau bisa juga sebaliknya. Oleh karena itu, jika semua karyawan sadar akan apa yang terbaik bagi perusahaan, maka peran sistem pengendalian manajemen tidak lagi dibutuhkan.

Penerapan sistem pengendalian manajemen tidak selalu efektif pada setiap perusahaan karena tergantung pada berbagai faktor. Lekatompessy (2012) menjelaskan bahwa keberhasilan SPM yang telah didesain tergantung pada budaya organisasi, khususnya untuk pengimplementasian strategi. Sejalan dengan teori kontingensi yang menyatakan bahwa tidak terdapat suatu sistem pengendalian umum yang secara tepat dapat diterapkan di semua organisasi. Budaya organisasi merupakan variabel kontingensi dan dapat dianggap sebagai self contingency variable (Gong dan Tse, 2009). Penyesuaian yang optimal antara sistem pengendalian dengan variabel kontingensi akan menghasilkan peningkatan kinerja individu maupun organisasi (Juanda, 2000).

Penelitian ini berfokus pada industri perhotelan. Hal ini didasari oleh pertimbangan bahwa industri perhotelan sangat peka terkait dengan budaya organisasi karena mereka berinteraksi langsung dengan para pelanggan (tamu). Hal ini juga didukung oleh pernyataan Woods (1989) yang mengemukakan bahwa industri perhotelan memiliki konteks budaya tertentu, dan mereka berbeda dari industri manufaktur karena lebih sulit untuk mengatur karyawan pada perusahaan jasa daripada manufaktur.

\section{KAJIAN LITERATUR DAN PENGEMBANGAN HIPOTESIS}

Kajian Literatur

Teori Kontingensi

Gagasan teori kontingensi dalam konteks akuntansi manajemen berkembang sejak tahun 1970-an sebagai upaya penjelasan berbagai variasi praktik akuntansi manajemen yang terlihat jelas. Teori ini sangat berfokus pada kontingensi struktur organisasi yang dikembangkan selama dua puluh tahun untuk menyusun struktur organisasi yang paling tepat dalam keadaan tertentu (Otley, 2016). Oleh karena itu, teori kontingensi digunakan untuk menganalisis desain dan sistem akuntansi manajemen sehingga dapat memberikan informasi yang 
tepat untuk digunakan perusahaan untuk berbagai macam tujuan, salah satunya untuk menghadapi persaingan (Mia dan Clarke, 1999).

Teori kontingensi menunjukkan tidak adanya rancangan dan penggunaan SPM yang dapat diterapkan secara efektif untuk semua kondisi organisasi, namun sebuah sistem pengendalian hanya efektif untuk kondisi tertentu atau organisasi tertentu atau perusahaan tertentu (Fisher, 1998). Menurut Otley (2016), sistem pengendalian dipengaruhi konteks bahwa mereka beroperasi dan harus disesuaikan kebutuhan dan keadaan organisasi tersebut.

Tema utama teori ini adalah bahwa penilaian kinerja perusahaan tergantung sekali pada kecocokan antara faktor kontekstual suatu organisasi (Cadez dan Guilding, 2008). Faktor-faktor misalnya teknologi, struktur organisasi, ukuran organisasi, strategi, lingkungan dan budaya organisasi.

\section{Budaya Organisasi}

Budaya organisasi adalah hasil proses mencairkan dan leburnya gaya budaya serta perilaku tiap individu yang dibawa sebelumnya, ke dalam norma dan filosofi yang baru dan akhirnya memiliki energi dan kebanggaan secara berkelompok dalam menghadapi sesuatu atau mencapai tujuan tertentu (Edison, Anwar, dan Komariah, 2016). Setiap organisasi umumnya jarang memiliki karakteristik hanya satu jenis budaya tetapi dalam perkembangannya organisasi akan memiliki satu budaya yang lebih dominan seiring dengan proses adaptasi dan respon terhadap perubahan dan tantangan yang ada di lingkungan organisasi (Schein, 2004). Cameron dan Quinn (1993, dalam Heryanto dan Augustine, 2017) mengembangkan Organizational Culture Assessment Instrument (OCAI) yang menilai budaya organisasi berdasarkan nilai inti, kepercayaan, dan asumsi. OCAI mendefinisikan 4 tipe budaya organisasi, yaitu clan culture, adaptive culture, mission culture, dan bureaucratic culture.

Salah satu alasan penting bagi sebuah organisasi untuk memiliki budaya yang kuat adalah jika organisasi tersebut mempunyai budaya yang kuat maka karyawan akan memberikan kesetiaan yang lebih besar dibandingkan dengan karyawan di dalam organisasi yang budaya organisasinya lemah (Robbins dan Coulter, 2016). Menurut Lako (2004), budaya organisasi yang memiliki kualitas baik di antaranya adalah:

1. Kuat, merupakan budaya organisasi yang dibangun serta dikembangkan akan mampu meningkatkan dan memengaruhi perilaku setiap individu pelaku organisasi (mulai pemilik, manajer, dan karyawan) sehingga dapat menyelaraskan tujuan individu serta kelompoknya sesuai dengan tujuan organisasi, serta mendorong para pelaku organisasi untuk memiliki goals (tujuan), objectives (sasaran) nilai dan kepercayaan, interaksi sosial, persepsi, perasaan, dan norma bersama yang merasuk ke setiap individu yang ada dalam organisasi sehingga mampu bekerja dan mampu mengekspresikan potensi yang dimilikinya ke arah tujuan yang sama.

2. Dinamis dan adaptif, yaitu budaya organisasi yang dibangun harus fleksibel dan responsif dalam dinamika lingkungan baik internal maupun eksternal organisasi yang cepat dan kompleks.

\section{Sistem Pengendalian Manajemen (SPM)}

SPM memegang peranan sangat penting di dalam sebuah perusahaan, karena pada dasarnya SPM didesain untuk mencapai tujuan organisasi. Anthony dan Govindarajan (2005) mengemukakan komponen SPM terdiri dari:

1. Pelacak atau sensor, yaitu perangkat yang mengukur apa yang terjadi sesungguhnya di dalam proses yang sedang dikendalikan.

2. Penilai, yaitu perangkat yang menentukan signifikansi peristiwa yang actual terjadi dengan membandingkan beberapa standar dengan ekspektasi dari apa yang seharusnya terjadi.

3. Umpan Balik (Effector), yaitu perangkat yang dapat mengubah perilaku apabila assessor mengindikasi bahwa ada kebutuhan untuk melakukan perubahan tersebut.

4. Jaringan komunikasi, yaitu perangkat yang meneruskan informasi di antara pelacak, penilai, dan effector.

Merchant dan Van der Stede (2018) menyebutkan bahwa beberapa pengendalian manajemen yang umum adalah supervisi langsung, seleksi dan retensi karyawan maupun kode etik, sehingga tidak hanya fokus pada pengukuran kinerja. Fokus lebih kepada pemberian dorongan, kesanggupan, atau juga, mendorong karyawan untuk melakukan yang terbaik bagi perusahaan. Sering kali pula, pengendalian manajemen bersifat proaktif daripada reaktif. Proaktif berarti pengendalian didesain untuk mencegah masalah sebelum mengalami hal-hal yang merugikan perusahaan sehingga dapat memengaruhi kinerja. Hal ini berarti walaupun pengendalian manajemen tidak berfokus untuk meningkatkan kinerja, tetapi pengendalian manajemen pada praktiknya akan memengaruhi kinerja. Kinerja Hotel 
Kinerja hotel merupakan hasil yang dapat dicapai oleh sekelompok orang yang bekerja pada suatu hotel dalam rangka menyediakan fasilitas dan pelayanan bagi para tamunya, sesuai dengan yang diinginkan perusahaannya. Kinerja organisasi berhubungan dengan serangkaian elemen yang menambah efektivitas organisasi, seperti produktivitas organisasi yang lebih tinggi, kesuksesan produk baru, loyalitas konsumen yang meningkat, peningkatan kualitas layanan yang dirasakan, return finansial yang lebih besar atau pertumbuhan perusahaan yang lebih cepat (Pedroche dkk., 2017). Menurut Corluka, Mikinac, dan Peronja (2017), kinerja hotel dapat dipengaruhi oleh faktor-faktor, yaitu (a) komponen internal seperti struktur, budaya, sumber daya, strategi, proses, sistem, produk, maupun peran dan tanggung jawab masing-masing individu; (b) komponen eksternal yang mengacu pada pasar dan industri dimana perusahaan beroperasi, yang menghasilkan ketidakpastian destination demand (permintaan tempat tujuan); dan (c) komponen temporal yaitu produk hotel sendiri yang memiliki sifat musiman sesuai dengan kebutuhan, motif, dan kebiasaan karena musimnya.

Menurut Sumarsono (2014), ada beberapa indikasi hotel yang sedang bertumbuh, antara lain:

1. Pangsa pasar hotel mengalami pertumbuhan tiap tahun, yang dapat dilihat dari jumlah tamu hotel yang makin banyak (okupansi naik), dan harga yang naik tiap tahun.

2. Hotel jadi bahan pembicaraan (yang positif) oleh banyak orang.

3. Memiliki inovasi dan kreativitas.

4. Mempunyai cash flow yang sehat dan tata kelola perusahaan yang benar (Good Corporate Management). Indikatornya karyawan sejahtera, gaji karyawan bagus, dicintai oleh customer-nya, dan keuntungan hotel bertambah baik. Sehingga akan tercipta "Happy Owner, Happy Guest, Happy Employee".

5. Value naik terus.

6. Bisa memberikan harga kamar ataupun produk lain dengan harga premium.

7. Percaya secara penuh kepada profesional ataupun pada manajemen yang mengelola.

\section{Pengembangan Hipotesis}

Budaya organisasi menjadi perekat bagi setiap individu dan memengaruhi mereka dalam hal bertindak dan berinteraksi dengan orang lain. Budaya organisasi dapat membuat karyawan merasa tergabung, diberdayakan, dan didukung (Robbins dan Coulter, 2016). Ketika nilai pokok organisasi dipahami secara jelas oleh para karyawan serta diterima secara luas, maka para karyawan akan mengetahui apa yang harus dikerjakan dan apa yang diharapkan dari mereka. Semakin besar komitmen yang dipunyai setiap karyawan terhadap perusahaan, ini berarti budaya dari perusahaan itu sendiri kuat, yang kemudian dapat mendukung peningkatan kinerja perusahaan melalui pengendalian dan motivasi karyawan sebagai alat untuk mencapai hal tersebut (Owoyemi dan Ekwoaba, 2014).

Setiap organisasi umumnya jarang memiliki karakteristik hanya satu jenis budaya tetapi dalam perkembangannya organisasi akan memiliki satu budaya yang lebih dominan (Schein, 2004). Oleh karena itu, budaya organisasi bersifat situasional. Budaya organisasi ditafsirkan sebagai faktor kontingensi dengan kejadian yang bervariasi (Allaire dan Firsirotu, 1984), sehingga budaya memengaruhi halhal lain. Sistem pengendalian akan berbeda terutama bila ditinjau dari budaya organisasi (Hofstede dkk.., 1990). Teori kontingensi menunjukkan sistem pengendalian dapat lebih menunjang pencapaian tujuan organisasi jika didesain sesuai dengan kondisi lingkungan organisasi (Hopwood, 1976).

Sistem pengendalian manajemen menjaga agar aktivitas perusahaan tetap berjalan sesuai dengan tujuan semula. Kegiatan-kegiatan dalam sistem pengendalian manajemen dijalankan oleh seluruh tingkatan organisasi, sehingga melibatkan interaksi dari manajemen puncak sampai tingkat karyawan. Sistem pengendalian manajemen diharapkan dapat mengendalikan perilaku setiap anggota organisasi dalam mencapai keselarasan tujuan (Anthony dan Govindarajan, 2005). Semakin erat keselarasan tujuan ini, maka semakin tinggi probabilitas pencapaian pada tujuan yang diinginkan bersama.

Sistem pengendalian manajemen jika dirancang dengan baik, dapat memengaruhi perilaku karyawan pada cara yang diharapkan dan, karenanya, meningkatkan profitabilitas yang dimana perusahaan akan mencapai tujuannya (Merchant dan Van der Stede, 2018). Alasan perusahaan perlu memiliki sistem pengendalian yang baik adalah ketika karyawan menggunakan kemampuan terbaiknya di tempat kerja, dampaknya adalah peningkatan kinerja perusahaan dan memperoleh keunggulan kompetitif, dan hal tersebut karena motivasi yang karyawan peroleh berasal dari kondisi pengendalian terbaik dalam perusahaan (Batool, 2011).

Berdasarkan kajian sebelumnya, maka hipotesis yang diajukan dalam penelitian ini adalah:

$\mathrm{H}_{1}$ : Budaya organisasi berpengaruh positif terhadap sistem pengendalian manajemen.

$\mathrm{H}_{2}$ : Budaya organisasi berpengaruh positif terhadap kinerja hotel. 
$\mathrm{H}_{3}$ : Sistem pengendalian manajemen berpengaruh positif terhadap kinerja hotel.

$\mathrm{H}_{4}$ : Sistem pengendalian manajemen memediasi hubungan antara budaya organisasi dengan kinerja hotel.

\section{Model Penelitian}

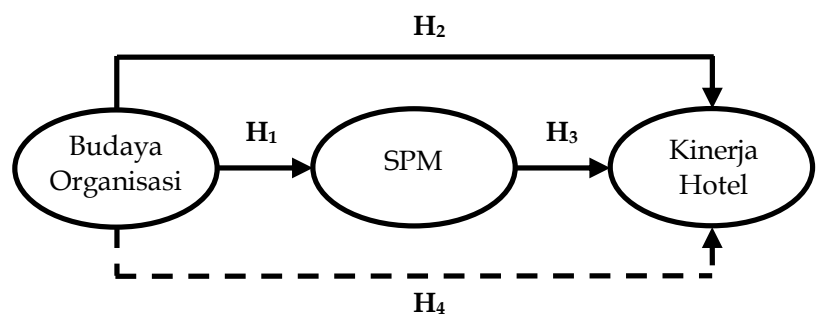

Gambar 1. Model Penelitian

\section{METODE PENELITIAN}

\section{Paradigma Penelitian}

Paradigma penelitian ini adalah penelitian eksplanatori dengan pendekatan kuantitatif. Peneliti berupaya menjelaskan hubungan interaktif antara variabel yang akan diteliti dan sejauh mana hubungan tersebut akan saling memengaruhi.

\section{Populasi dan Sampel Penelitian}

Populasi penelitian ini adalah manajer dan kepala departemen yang bekerja aktif pada hotel berbintang di Kota Makassar. Teknik pemilihan sampel adalah purposive sampling. Target responden sebanyak 60 orang. Kriteria sampel dalam penelitian ini:

1. Kepala departemen atau manajer yang bekerja pada hotel bintang 3, 4 dan 5 dan yang berada di Kota Makassar, maksimal 3 orang dari masing-masing hotel.

2. Hotel berbintang yang digunakan telah beroperasi selama lebih dari setahun di lokasinya (bukan merupakan perusahaan startup). Hal ini didasari pada pertimbangan agar budaya organisasi yang berlaku di hotel tersebut bukan berada dalam tahap pertumbuhan dan sistem pengendalian manajemennya telah stabil.

\section{Variabel Penelitian}

Budaya organisasi dalam penelitian ini merupakan variabel independen (X1). Budaya organisasi adalah suatu hasil peleburan perilaku setiap orang yang dibawa dari luar organisasi melalui nilai dan norma yang dianut bersama oleh para anggota organisasi yang membedakannya dari organisasi lain. Variabel ini diukur menggunakan 9 item pernyataan yang mewakili 4 tipe budaya organisasi dalam
OCAI yang dikembangkan oleh Cameron dan Quinn dalam Chang dan Lee (2007); Ong, Magsi dan Burgess (2019), yaitu clan culture, mission culture, adaptive culture, bureaucratic culture. Semua pernyataan diukur dengan skala Likert yang memiliki rentang skor 1 sampai 7 dengan keterangan sebagai berikut: 1 (sangat tidak setuju); 4 (netral); dan 7 (sangat setuju). Semakin tinggi skor menunjukkan budaya organisasi yang dianut perusahaan memiliki kualitas yang baik.

SPM merupakan variabel mediasi (Y1) dalam penelitian ini. SPM merupakan sistem yang digunakan manajer agar dapat memastikan implementasi rencana dapat dicapai oleh perusahaan melalui pemberian dorongan dan kesanggupan bagi karyawan untuk melakukan yang terbaik bagi perusahaan serta mencegah masalah agar tidak merugikan perusahaan. Variabel SPM diukur melalui 21 item pernyataan yang mewakili masing-masing elemen sistem pengendalian manajemen yaitu result control, action control, personnel control, dan culture control (Goebel dan Weißenberger, 2016). Semua pernyataan diukur dengan skala Likert yang memiliki rentang skor 1 sampai 7 dengan keterangan sebagai berikut: 1 (sangat tidak setuju); 4 (netral); dan 7 (sangat setuju). Semakin tinggi skor menunjukkan semakin tinggi sistem pengendalian manajemen perusahaan.

Kinerja hotel merupakan variabel dependen (Y2) dalam penelitian ini. Kinerja hotel adalah hasil yang dapat diperoleh sekelompok orang yang bekerja pada suatu hotel dalam rangka menyediakan fasilitas dan pelayanan bagi para tamunya, sesuai dengan yang diinginkan perusahaannya. Variabel kinerja hotel diukur melalui 4 item pernyataan yang mewakili 4 elemen yang mendorong kinerja perusahaan (hotel) menurut Pedroche, dkk. (2017), yaitu operating results, customer loyalty, improvement in quality, dan business competencies. Semua pernyataan diukur dengan skala Likert yang memiliki rentang skor 1 sampai 7 dengan keterangan sebagai berikut: 1 (sangat buruk); 4 (netral); dan 7 (sangat baik). Semakin tinggi skor menunjukkan semakin baik kinerja hotel tersebut.

\section{Metode Analisis}

Metode analisis dalam peneltian ini berfokus pada analisis jalur (path analysis). Analisis jalur adalah perluasan dari analisis regresi linear berganda yang digunakan untuk menaksir hubungan kausalitas antar variabel yang telah ditetapkan sebelumnya berdasarkan teori. Koefesien jalur dihitung dengan membuat dua persamaan struktural yaitu persamaan regresi yang menunjukkan hubungan 
yang dihipotesiskan.

$$
\begin{aligned}
& y_{1}=p_{1} x_{1}+\varepsilon_{1} \\
& y_{2}=p_{2} x_{1}+p_{2} y_{1}+\varepsilon_{2}
\end{aligned}
$$

Keterangan:

$\mathrm{x}_{1}$ = Budaya Organisasi (BO)

$\mathrm{y}_{1}=$ Sistem Pengendalian Manajemen (SPM)

$\mathrm{y}_{2}=$ Kinerja Hotel $(\mathrm{KH})$

$\varepsilon=$ Unexplained Variance

\section{HASIL DAN PEMBAHASAN}

Hasil Penelitian

Statistik Deskriptif

Tabel 1. Hasil Uji Deskriptif

\begin{tabular}{|c|c|c|c|c|}
\hline Variabel & Mean & $\begin{array}{c}\text { Std. } \\
\text { Devi- } \\
\text { asi }\end{array}$ & $\begin{array}{c}\text { Kis. } \\
\text { Aktual }\end{array}$ & $\begin{array}{c}\text { Kis. } \\
\text { Teori- } \\
\text { tis }\end{array}$ \\
\hline $\begin{array}{c}\text { Budaya } \\
\text { Organisasi }\end{array}$ & 53,70 & 3,61 & $46-63$ & $9-63$ \\
\hline SPM & 123,93 & 8,83 & $\begin{array}{c}102- \\
146\end{array}$ & $21-147$ \\
\hline $\begin{array}{c}\text { Kinerja } \\
\text { Hotel }\end{array}$ & 24,63 & 1,93 & $20-28$ & $4-28$ \\
\hline
\end{tabular}

Variabel budaya organisasi secara teoritis memiliki nilai minimum adalah 9 dan nilai maksimum adalah 63 dengan standar deviasi yang diperoleh adalah sebesar 3,61. Sedangkan, jawaban yang diberikan oleh responden untuk variabel budaya organisasi berkisar antara 46 sampai 63. Nilai rata-rata (mean) adalah 53,70 lebih mendekati nilai maksimum 63. Hal ini mengindikasikan bahwa jawaban responden cenderung setuju mengenai budaya organisasi yang berlaku di hotelnya. Dapat disimpulkan bahwa budaya organisasi yang dianut oleh hotel-hotel yang menjadi sampel penelitian memiliki kualitas yang baik.

Variabel SPM secara teoritis memiliki nilai minimum adalah 21 dan nilai maksimum adalah 147 dengan standar deviasi yang diperoleh adalah sebesar 8,83 . Sedangkan, jawaban yang diberikan oleh responden untuk variabel sistem pengendalian manajemen berkisar antara 102 sampai 146. Nilai ratarata (mean) sebesar 123,93 lebih mendekati nilai maksimum 147. Hal ini mengindikasikan bahwa jawaban responden cenderung setuju mengenai sistem pengendalian manajemen yang dianut di hotelnya. Maka dapat disimpulkan bahwa sistem pengendalian manajemen yang dianut oleh hotel-hotel yang menjadi sampel penelitian berjalan dengan efektif.

Variabel kinerja hotel secara teoritis mempunyai nilai minimum 4 dan nilai maksimum 28 dengan standar deviasi sebesar 1,93. Sedangkan, jawaban yang diberikan oleh responden untuk variabel kinerja hotel berkisar antara 20 sampai 28 . Nilai rata-rata (mean) adalah 24,63 lebih mendekati nilai maksimum 28. Hal ini mengindikasikan bahwa jawaban responden cenderung baik mengenai kinerja hotelnya. Dapat disimpulkan bahwa kinerja hotel yang menjadi sampel penelitian sangat baik.

\section{Hasil Pengujian Model}

Uji Model (F) ini digunakan untuk menguji variabel independen secara simultan atau bersamasama berpengaruh signifikan terhadap variabel dependen. Uji F menguji apakah model yang dibuat sudah layak yang dilihat dari besarnya nilai probabilitas ( $p$ value) dibandingkan dengan 0,05 (taraf signifikansi $\alpha=5 \%$ ).

Tabel 2. Hasil Uji F

\begin{tabular}{|c|c|c|}
\hline Model Substruktur & F & Sig. \\
\hline Substruktur 1 & 80,494 & 0,000 \\
\hline Substruktur 2 & 41,639 & 0,000 \\
\hline
\end{tabular}

Hasil uji F pada tabel 2 menunjukkan bahwa untuk persamaan substruktur 1 yang menguji pengaruh budaya organisasi terhadap sistem pengendalian manajemen memiliki nilai signifikansi 0,00 . Angka ini menunjukkan bahwa terdapat pengaruh budaya organisasi terhadap sistem pengendalian manajemen. Sehingga dapat disimpulkan bahwa persamaan substruktur 1 yang dibangun telah baik.

Selain itu, hasil uji F pada tabel 2 juga menunjukkan persamaan substruktur 2 yang menguji pengaruh budaya organisasi dan sistem pengendalian manajemen terhadap kinerja hotel memiliki nilai signifikansi 0,00 . Hal ini menunjukkan bahwa terdapat pengaruh budaya organisasi dan sistem pengendalian manajemen terhadap kinerja hotel. Sehingga dapat disimpulkan bahwa persamaan substruktur 2 yang dibangun telah baik.

\section{Hasil Uji Koefisien Determinasi (Uji $\left.R^{2}\right)$}

Uji koefisien determinasi dalam penelitian ini digunakan untuk mengukur seberapa jauh kemampuan variasi variabel independen menerangkan variasi variabel dependen. Koefisien determinasi yang digunakan dalam penelitian ini adalah adjusted $R^{2}$.

Tabel 3. Hasil Uji R ${ }^{2}$

\begin{tabular}{|c|c|}
\hline Model Substruktur & Adjusted $R^{2}$ \\
\hline Substruktur 1 & 0,574 \\
\hline Substruktur 2 & 0,579 \\
\hline
\end{tabular}


Besarnya nilai adjusted $R^{2}$ pada substruktur 1 adalah 0,574 atau sebesar $57,4 \%$, yang berarti bahwa variabel budaya organisasi mampu menjelaskan variabel sistem pengendalian manajemen sebesar $57,4 \%$ dan sisanya $42,6 \%$ dijelaskan variabel-variabel lain yang berada di luar model yang tidak dimasukkan dalam analisis ini.

Besarnya nilai adjusted $R^{2}$ pada substruktur 2 adalah 0,579 atau sebesar $57,9 \%$, yang berarti bahwa variabel budaya organisasi dan sistem pengendalian manajemen mampu menjelaskan variabel kinerja hotel sebesar $57,9 \%$ dan $42,1 \%$, sisanya, dijelaskan oleh variabel-variabel lain yang berada di luar model penelitian ini.

\section{Hasil Analisis Jalur (Path Analysis)}

Untuk mengetahui pola hubungan ketiga variabel penelitian ini, dilakukan pengujian terhadap empat hipotesis dengan menggunakan analisis jalur untuk menguji pengaruh secara simultan dari setiap variabel eksogen terhadap variabel endogen.

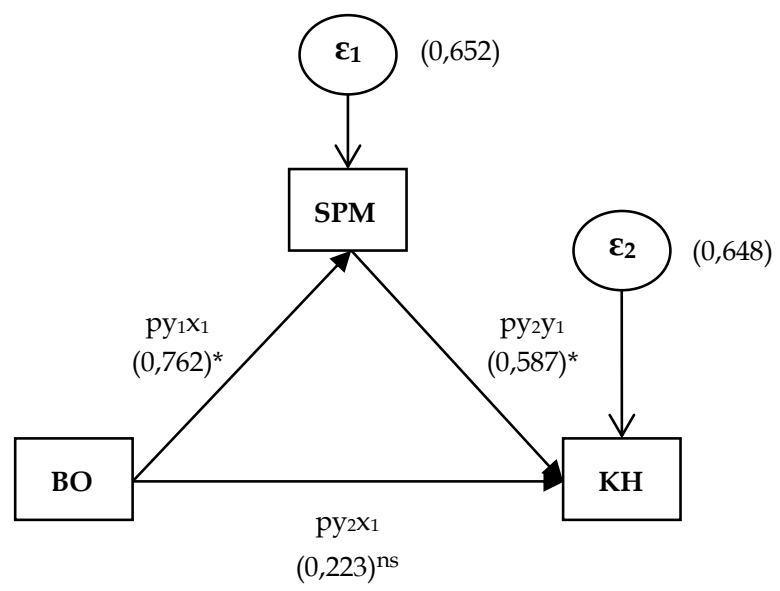

Gambar 2. Model Analisis Jalur

Keterangan:

$\begin{array}{ll}* & \text { : Significant (2-Tailed) } \\ \text { ns } & \text { : Nonsignificant }\end{array}$

Persamaan struktural yang dapat dirumuskan berdasarkan model analisis jalur sesuai gambar 2 adalah:

Persamaan substruktur 1:

$\mathrm{y}_{1}=0,762+0,652$

Persamaan substruktur 2:

$\mathrm{y}_{2}=0,223+0,587+0,648$

Keterangan:

$\mathrm{E}_{1}=\sqrt{\mathbf{1 - \text { Adjusted } \boldsymbol { R } ^ { \mathbf { 2 } }}}=\sqrt{\mathbf{1 - 0 , 5 7 4}}=0,652$

$\mathrm{E}_{2}=\sqrt{\mathbf{1 - \text { Adjusted } \boldsymbol { R } ^ { \mathbf { 2 } }}}=\sqrt{\mathbf{1 - 0 , 5 7 9}}=0,648$
Berdasarkan persamaan struktural yang dirumuskan tersebut, persamaan substruktur 1 memiliki makna bahwa budaya organisasi berpengaruh positif terhadap variabel sistem pengendalian manajemen. Artinya, budaya organisasi yang memiliki kualitas yang baik secara statistik dapat meningkatkan sistem pengendalian manajemen pada hotel.

Selanjutnya, persamaan substruktur 2 memiliki makna bahwa variabel budaya organisasi dan sistem pengendalian manajemen berpengaruh positif terhadap variabel kinerja hotel. Artinya, dengan semakin tingginya budaya organisasi dan sistem pengendalian manajemen secara statistik dapat mendorong peningkatan kinerja hotel.

Pengujian Hipotesis (Uji t)

Uji $t$ menunjukkan pengaruh variabel independen secara individual dalam menerangkan variasi variabel dependen. Jika nilai probabilitas lebih kecil dari 0,05 (taraf signifikansi $\alpha=5 \%$ ), maka terjadi pengaruh parsial secara signifikan, variabel independen terhadap variabel dependen.

Tabel 4. Hasil Uji t

\begin{tabular}{|l|c|c|c|}
\hline \multicolumn{1}{|c|}{ Model Substruktur } & $\begin{array}{c}\text { Std. } \\
\text { Coef. }\end{array}$ & Sig. & Ket. \\
\hline $\begin{array}{l}\text { Substruktur 1 } \\
\text { Budaya Organisasi* }^{*}\end{array}$ & 0,762 & 0,000 & Signifikan \\
\hline $\begin{array}{l}\text { Substruktur 2 } \\
\text { Budaya Organisasi** }\end{array}$ & 0,223 & 0,092 & $\begin{array}{c}\text { Tidak Sig- } \\
\text { nifikan }\end{array}$ \\
\hline $\begin{array}{l}\text { Sistem Pengendalian } \\
\text { Manajemen }\end{array}$ & 0,587 & 0,000 & Signifikan \\
\hline
\end{tabular}

* Variabel Dependen: SPM

** Variabel Dependen: Kinerja Hotel

Pengaruh budaya organisasi terhadap SPM adalah 0,762 dengan probabilitas nilai signifikansi 0,000 $<0,05$. Angka ini menunjukkan budaya organisasi berpengaruh positif dan signifikan terhadap sistem pengendalian manajemen. Dapat disimpulkan, hipotesis pertama $\left(\mathrm{H}_{1}\right)$ yang menyatakan bahwa budaya organisasi berpengaruh positif terhadap sistem pengendalian manajemen, diterima.

Pengaruh budaya organisasi terhadap kinerja hotel adalah sebesar 0,223 dengan probabilitas nilai signifikansi 0,092 >0,05. Hal ini menunjukkan bahwa budaya organisasi berpengaruh positif namun tidak signifikan terhadap kinerja hotel. Dapat disimpulkan, hipotesis kedua $\left(\mathrm{H}_{2}\right)$ yang menyatakan bahwa budaya organisasi berpengaruh positif terhadap kinerja hotel, ditolak.

Pengaruh sistem pengendalian manajemen terhadap kinerja hotel adalah 0,587 dengan probabili- 
tas nilai signifikansi $0,000<0,05$. Angka ini menunjukkan bahwa sistem pengendalian manajemen berpengaruh positif dan signifikan terhadap kinerja hotel. Dapat disimpulkan bahwa hipotesis ketiga $\left(\mathrm{H}_{3}\right)$ yang menyatakan sistem pengendalian manajemen berpengaruh positif terhadap kinerja hotel, diterima.

\section{Hasil Uji Sobel (Sobel Test)}

Uji sobel bertujuan untuk menguji kekuatan pengaruh secara tidak langsung variabel independen terhadap variabel dependen melalui variabel intervening. Hasil uji sobel yang memiliki tingkat signifikansi kurang dari 0,05 mengindikasikan adanya peran variabel intervening terhadap pengaruh variabel independen ke variabel dependen.

Tabel 5. Hasil Uji Sobel

\begin{tabular}{|c|c|c|c|c|c|}
\hline $\mathrm{A}$ & $\mathrm{B}$ & $\mathrm{SE}_{\mathrm{a}}$ & $\mathrm{SE}_{\mathrm{b}}$ & Probabilitas & Ket. \\
\hline 1,861 & 0,128 & 0,207 & 0,029 & 0,00007431 & Signifikan \\
\hline
\end{tabular}

Keterangan:

a = Koefisien regresi pengaruh variabel independen ke variabel intervening

$\mathrm{b}=$ Koefisien regresi pengaruh variabel intervening ke variabel dependen

$\mathrm{SE}_{\mathrm{a}}=$ Standar error dari koefisien a

$\mathrm{SE}_{\mathrm{b}}=$ standar error dari koefisien $\mathrm{b}$

Tabel 5, hasil uji sobel, menunjukkan pengaruh budaya organisasi (X1) terhadap kinerja hotel (Y2) melalui sistem pengendalian manajemen (Y1) memperoleh probabilitas signifikansi 0,00007431, yang lebih kecil dari 0,05. Dapat disimpulkan, hipotesis ke-empat $\left(\mathrm{H}_{4}\right)$ yang menyatakan bahwa sistem pengendalian manajemen memediasi hubungan antara budaya organisasi dengan kinerja hotel, diterima.

\section{Pembahasan}

Hasil penelitian ini menyatakan bahwa budaya organisasi berpengaruh positif dan signifikan terhadap SPM. Hasil penelitian ini membuktikan bahwa budaya organisasi berperan penting dalam pelaksanaan sistem pengendalian manajemen yang diadopsi oleh hotel. Semakin baik budaya organisasi suatu hotel, maka sistem pengendalian manajemen yang berlaku lebih tinggi.

Hasil penelitian ini konsisten dengan hasil penelitian Reginato dan Guerriro (2013), yaitu budaya organisasi mempunyai pengaruh signifikan terhadap sistem pengendalian manajemen. Hasil penelitian ini tidak hanya menemukan pengaruh signifikan dari budaya organisasi terhadap sistem pengendalian manajemen, tetapi juga adanya pengaruh positif antara budaya organisasi dengan SPM. Hubungan ini terbukti karena budaya organisasi yang dimiliki oleh sebagian besar hotel berbintang di Kota Makassar adalah kombinasi dari empat tipe budaya organisasi.

Berdasarkan teori kontingensi, desain dan sistem pengendalian manajemen adalah tergantung pada faktor situasional yang berbeda-beda di setiap organisasi, dimana budaya organisasi merupakan salah satu faktornya. Budaya yang ditandai dengan sifat kekeluargaan yang tinggi menjadikan para karyawan memiliki kerja sama yang baik antar tim dan manajer dipandang sebagai seorang mentor. Dengan suasana kerja yang nyaman ini, manajer cenderung dekat dengan karyawan sehingga nilainilai inti dari perusahaan memotivasi karyawan. Adapun perusahaan yang sering mengadakan training dan aktivitas pengembangan lainnya, hal ini karena karyawannya memiliki keberanian untuk berinovasi dan bereksperimen. Perusahaan menjadi selektif dalam memilih karyawan baru karena mereka menginginkan karyawan yang sesuai dengan kepribadian mereka. Prosedur dan operasi standar yang sangat diutamakan berarti perusahaan menjadi tempat kerja yang terstruktur sehingga manajer memperhatikan setiap langkah yang diambil oleh karyawan dimana manajer banyak mengambil peran dalam mengevaluasi tugas-tugas yang diselesaikan karyawan.

Olahan data statistik dari riset ini menemukan bahwa budaya organisasi tidak memiliki pengaruh terhadap kinerja hotel. Hal ini mengindikasikan budaya organisasi yang telah dibangun dalam suatu organisasi tidak secara langsung mempengaruhi kinerja hotel.

Hasil penelitian ini sesuai dengan temuan penelitian Heryanto dan Augustine (2017). Bertolak belakang dengan temuan penelitian Himmer (2013) serta Nazarian, Atkinson dan Foroudi (2017) yang menunjukkan bahwa budaya organisasi berpengaruh positif terhadap kinerja hotel. Temuan yang bertolak belakang ini dapat disebabkan karena jumlah skor terendah terdapat pada indikator mission culture dibandingkan indikator budaya lainnya, yang berarti bahwa budaya organisasi pada hotel berbintang di Kota Makassar cenderung kurang didominasi oleh pencapaian target.

Hal tersebut di atas setidaknya terkonfirmasi dari pernyataan Kotter dan Heskett (1992) yang menggariskan bahwa budaya organisasi yang kuat dapat menciptakan kinerja yang unggul, namun berdasarkan pengalaman yang terjadi pada 200 perusahaan yang diteliti ternyata tidak mendukung teori tersebut. Beberapa penelitian lain juga hanya 
mendukung hubungan tidak langsung antara budaya organisasi terhadap kinerja melalui mediasi seperti konversi pengetahuan (Tseng, 2010), manajemen pengetahuan (Zheng, Yang, dan McLean, 2010), dan inovasi (Han, Kim, dan Srivastava, 1998). Hal ini memperkuat temuan peneliti bahwa pengaruh budaya organisasi terhadap kinerja hotel adalah tidak langsung. Artinya budaya organisasi mendukung kinerja hotel dengan melalui faktor lain.

Temuan selanjutnya dari penelitian saat ini menunjukkan bahwa SPM berpengaruh positif dan signifikan terhadap kinerja hotel. Temuan ini memberi pesan bahwa sistem pengendalian manajemen cenderung meningkatkan kinerja hotel. Semakin baik SPM yang berlaku, maka kinerja hotel menjadi lebih tinggi.

Hasil penelitian ini sejalan dengan hasil penelitian Duréndez, dkk. (2016) yang berhasil membuktikan bahwa SPM memiliki pengaruh positif terhadap kinerja perusahaan. Hasil penelitian ini juga konsisten dengan hasil penelitian Jamil dan Mohamed (2013) yang menemukan pengaruh positif dan signifikan antara sistem pengendalian manajemen dengan kinerja hotel. Hal ini terbukti karena hotel berbintang di Kota Makassar cenderung menerapkan sebagian besar elemen sistem pengendalian manajemen dengan baik.

Manajer hotel menggunakan sistem pengendalian manajemen sebagai alat untuk memastikan tujuan perusahaan tercapai. Dengan adanya imbalan untuk hasil yang ditargetkan, karyawan berusaha melakukan pekerjaannya dengan baik agar memperoleh imbalan tersebut. Pengendalian hasil memastikan karyawan mengetahui target apa yang ingin dicapai perusahaan sehingga hasil operasi hotel bisa meningkat. Hotel memiliki prosedur kerja seperti penataan kamar, kebersihan, dan hidangan makanan. Hal ini berarti prosedur kerja serta standar ini sangat penting dilakukan karena akan memengaruhi kualitas layanan hotel. Karyawan perlu mengetahui bagaimana cara memenuhi standar yang diberlakukan hotel. Ketika karyawan hotel dipilih dengan sangat selektif, artinya karyawan yang bekerja dipastikan memiliki kemampuan yang dibutuhkan perusahaan. Selain itu, dengan melakukan pelatihan dapat meningkatkan kemungkinan pekerjaan dilakukan dengan lebih baik. Kualitas layanan yang diberikan dapat meningkat dengan pengembangan dan inovasi dari karyawan.

Hasil uji sobel (tabel 5) dalam penelitian ini menunjukkan bahwa sistem pengendalian manajemen dapat memediasi hubungan antara budaya organisasi dengan kinerja hotel, yang ditunjukkan dengan probabilitas signifikansi. Hal ini berarti budaya organisasi berpengaruh yang signifikan terhadap kinerja hotel jika melalui sistem pengendalian manajemen.

Hasil penelitian ini membuktikan peranan sistem pengendalian manajemen sebagai pemediasi yang sebelumnya juga telah dilakukan oleh Zuriana, Jamil dan Mohamed (2013). Budaya organisasi sendiri berpengaruh langsung yang tidak signifikan terhadap kinerja hotel, sehingga adanya perantara sistem pengendalian manajemen menjadi lebih baik bagi hubungan tersebut.

Budaya organisasi sejatinya merancang perilaku karyawan hotel dan hal tersebut dapat berpengaruh secara langsung terhadap kinerja individu (Druckman, Singer, dan Van Cott, 1997). Namun, kinerja individu tidak selalu dapat ditafsirkan sebagai kinerja hotel. Hal ini karena fokus dari budaya adalah pada individunya. Perusahaan melakukan pengendalian yang sesuai sebagai jalan untuk mengendalikan karyawannya dimana sistem pengendalian manajemen sendiri berfokus pada pencapaian tujuan yang diinginkan perusahaan. Desain dan sistem pengendalian manajemen dibentuk oleh perusahaan sesuai dengan budaya organisasinya. Kepatuhan karyawan terhadap aturan yang dibuat oleh perusahaan dapat membuat proses operasi hotel berjalan dengan lancar. Ketika atasan menentukan langkah kerja yang paling penting dalam tugas-tugas karyawan, maka pekerjaan yang dihasilkan dapat lebih baik dibandingkan hotel lain karena adanya inovasi untuk melakukan peningkatkan layanan hotel.

\section{SIMPULAN}

Kesimpulan dalam penelitian ini bahwa suatu sistem pengendalian manajemen merupakan sebuah mekanisme yang dapat digunakan untuk mendorong penguatan dan internalisasi budaya organisasi untuk mencapai kinerja hotel. Hal ini terkonfirmasi dari hasil penelitian yang menunjukkan bahwa budaya organisasi tidak berpengaruh secara langsung terhadap kinerja hotel, namun demikian sistem pengendalian manajemen berpengaruh positif terhadap kinerja hotel. Demikian halnya, berdasarkan pengujian sobel, terkonfirmasi bahwa budaya organisasi memiliki pengaruh signifikan terhadap kinerja hotel melalui mekanisme sistem pengendalian manajemen. Hasil ini mengindikasikan bahwa sistem pengendalian manajemen mampu memediasi budaya organisasi terhadap kinerja hotel. Dengan kata lain bahwa budaya organisasi yang baik memudahkan manajer melakukan pengendalian melalui sistem 
pengendalian manajemen sehingga manajer mampu melakukan tindakan pencegahan dari kegagalan karyawan dan mendorong karyawan melakukan tugas dengan baik, sehingga akan meningkatkan kinerja hotel.

Secara teoritis temuan riset ini konsisten dan sejalan dengan argumentasi teori kontingensi yang menyatakan budaya organisasi memiliki pengaruh terhadap sistem pengendalian manajemen. Aspekaspek kontekstual dari pengendalian manajemen membantu menginternalisasikan budaya organisasi untuk mendorong kinerja suatu perusahaan. Selain itu, hasil penelitian ini mendukung teori Druckman, Singer, dan Van Cott (1997) yang menyatakan bahwa budaya organisasi tidak dapat memengaruhi kinerja secara langsung sehingga dalam menilai pengaruh budaya pada kinerja, kita harus menentukan jalan dimana budaya itu akan memengaruhi orang dan bagaimana pengaruh itu dapat dikaitkan dengan kinerjanya.

Manajemen hotel dalam meningkatkan kinerjanya perlu meletakkan perhatian yang lebih pada budaya organisasinya. Salah satu cara efektif untuk menguatkan budaya organisasi yang ditemukan dalam penelitian ini adalah melalui sistem pengendalian manajemen yang baik. Hal ini sesuai dengan pernyataan Kamau dan Wanyoike (2019) bahwa untuk meningkatkan kinerja organisasi, budaya perusahaan harus mendukung dan sesuai dengan strategi dan aktivitas sehari-hari karyawan. Sehingga fokus utama dari budaya organisasi yang dibangun oleh hotel mengharuskan untuk meningkatkan sistem pengendalian manajemennya terlebih dahulu, yang selanjutnya akan meningkatkan kinerja hotelnya.

Keterbatasan dalam penelitian ini adalah response rate saat pengumpulan data kurang tinggi, sehingga belum mampu mengeneralisasi penelitian ini. Berdasarkan temuan-temuan dalam penelitian ini, penelitian berikutnya dapat menambahkan variabel eco-innovation (Santiago, Medina dan Pichardo, 2017).

\section{REFERENCES}

Allaire, Y., dan Firsirotu, M. E. (1984). Theories of Organizational Culture. Organization Studies, 193-226.

Anthony, R. N., dan Govindarajan, V. (2005). Management Control System. Jakarta: Salemba Empat.

Batool, S. (2011). Analyze the Factors that Have an Influence on the Management Control System. Research Journal of Finance and Accounting, 2, 4855 .

Cadez, S., dan Guilding, C. (2008). An Exploratory
Investigation of an Integrated Contingency Model of Strategic Management Accounting. Accounting Organizations and Society, 33(7-8), 836-863.

Chang, S., dan Lee, M. (2007). A Study on Relationship among Leadership, Organizational Culture, the Operation of Learning Organization and Employees' Job Satisfaction. The Learning Organization, 14(2), 155-185.

Choi, J., Woods, R. H., dan Muramann, S. K. (2000). International Labor Markets and the Migration of Labor Forces as an Alternative Solution for Labor Shortages in the Hospitality Industry. International Journal of Contemporary Hospitality Management, 12(1), 61-66.

Clarke, H. D., dan Iles, P. (2000). Climate for Diversity and Its Effects on Career and Organisational Attitudes and Perceptions. Personnel Review, 29(3), 324-345.

Corluka, G., Mikinac, K., dan Peronja, I. (2017). How to Approach Hotel Performance Measurement? A Conceptualization of Key Determinants. Didapatkan dari https://www.researchgate.net/publication/32 1132272_HOW_TO_APPROACH_HOTEL_PE RFORMANCE_MEASUREMENT_A_CONCE PTUALIZATION_OF_KEY_DETERMINANTS, 7 Juli 2020, 10.40 WIB.

Daromes, F. E., Ng, S., dan Kampo, K. (2018). Memahami Strategi Implementasi Sistem Pengendalian Manajemen Komprehensif. Balance: Jurnal Akuntansi, Auditing dan Keuangan, (15)1, 34-73.

Dewantara, I. W. G. S., Ali, M., dan Sudirman, I. (2010). Evaluasi Kinerja Inisiatif Manajemen Pemeliharaan Menggunakan Kriteria Malcolm Baldrige (Suatu Pendekatan KualitatifEvaluatif). Didapat dari https://www.academia.edu/1928070/EVALU ASI_KINERJA_INISIATIF_MANAJEMEN_PE MELIHARAAN_MENGGUNAKAN_KRITERI A_MALCOLM_BALDRIGE_SUATU_PENDEK ATAN_KUALITATIF_, 6 Juni 2020, pukul 12.45 WIB.

Druckman, D., Singer, J. E., dan Van Cott, H. (1997). Enhancing Organizational Performance. Washington D.C.: National Academy.

Duréndez, A., Ruíz-Palomo, D., García-Pérez-deLema, D., dan Diéguez-Soto, J. (2016). Management Control System and Performance in Small and Medium Family Firms. European Journal of Family Business, 6(1), 10-20.

Edison, E., Anwar, Y., dan Komariah, I. (2016). 
Manajemen Sumber Daya Manusia. Bandung: Alfabeta.

Fisher, J. G. (1998). Contingency Theory, Management Control System and Firm Outcomes: Past Results and Future Directions. Behavioural Research in Accounting, 10, 47-64.

Goebel, S., dan Weißenberger, B. E. (2016). Effects of Management Control Mechanism: Towards A More Comprehensive Analysis. Journal of Business Economics, 87(2), 185-219.

Gong, M. Z., dan Tse, M. S. C. (2009). Pick, Mix or Match? A Discussion of Theories for Management Accounting Research. Journal of Accounting, Business and Management, 16(2), 5466.

Han, J. K., Kim, N., dan Srivastava, R. K. (1998). Market Orientation and Organizational Performance: Is Innovation a Missing Link? Journal of Marketing, 62(4), 30-45.

Herlinda, W. D. (2019, Februari 17). Jumlah Kamar Berlebihan, Hotel di Indonesia Disarankan Rem Ekspansi. Ekonomi.bisnis.com, p. 1.

Heryanto, G., dan Augustine, Y. (2017). The Influence of Organizational Culture on Corporate Performance: Using Management Accounting System as the Mediating Variable. OIDA International Journal of Sustainable Development, 10(1), 35-48.

Himmer, N. S. (2013). How Does Organizational Culture Influence the Performance of Luxury Hotels Based on the Example of Ritz-Carlton Hotel Company L.L.C? (Bachelor Thesis, Bachelor of Business Administration Tourism dan Hospitality Management, Vienna University, Wina, Austria). Didapat dari https://www.modul.ac.at/uploads/files/The ses/Bachelor/Thesis-2013-

Himmer_Thesis.pdf.

Hofstede, G., Neuijen, B., Ohayv, D. D., dan Sanders, G. (1990). Measuring Organizational Cultures: A Qualitative and Quantitative Study Across Twenty Cases. Administrative Science Quarterly, 35(2), 286-316.

Hopwood, A. G. (1976). Accounting and Human Behaviour. New South Wales: Haymarket Publishing Limited.

Juanda, A. (2000). Analisa Historis-Dialectical dan Penerapan Sistem Pengendalian Manajemen. Jurnal Ilmiah Bestari, 13(30) 43-51.

Kamau, P., dan Wainyoike, R. (2019). Corporate Culture and Organizational Performance: A Case of Mayfair Casino, Nairobi City Country, Kenya. Global Journal of Commerce and Management Perspective, 8(1), 8-17.
Kampo, K. (2020). Memahami Nilai Pemberdayaan Credit Union. Jurnal Sistem Informasi, Manajemen dan Akuntansi (SIMAK), 18(2), 217-233.

Kotter, J. P., dan Heskett, J. L. (1992). Corporate Culture and Performance. New York: Free Press.

Lako, A. (2004). Kepemimpinan dan Kinerja Organisasi: Isu Teori dan Solusi. Yogyakarta: Amara Books.

Lekatompessy, J. E. (2012). Peran Sistem Pengendalian Manajemen dalam Meningkatkan Kinerja Perusahaan: Analisis Kontinjensi dan Resource-Based View. (Disertasi, Program Studi Doktor Ilmu Ekonomi Universitas Diponegoro, Semarang, Indonesia). Didapat dari http:/ /eprints.undip.ac.id/40889/1/bab_13.pdf.

Merchant, K. A., dan Van der Stede, W. A. (2018). Sistem Pengendalian Manajemen (Edisi ke-3). Jakarta: Salemba Empat.

Mia, L., dan Clarke, B. (1999). Market Competition, Management Accounting System and Business Unit Performance. Management Accounting Research, 10(2), 137-158.

Mitrović, M., Janković, S., dan Ivankovič, G. (2016). Hotel Performance Measurement: Literature Review. Didapat dari https://www.researchgate.net/publication/31 0624220_Hotel_performance_measurement_lit erature_review, 12 Juni 2020, pukul 17:20 WIB.

Nazarian, A., Atkinson, P., dan Foroudi, P. (2017). Influence of National Culture and Balanced Organizational Culture on the Hotel's Industry Performance. International Journal of Hospitality Tourism, 63, 22-32.

Ong, T. S., Magsi, H. B., dan Burgess, T. F. (2019). Organisational Culture, Environmental Management Control Systems, Environmental Performance of Pakistani Manufacturing Industry. International Journal of Productivity and Performance Management, 68(7), 1293-1322.

Otley, D. (2016). The Contingency Theory of Management Accounting and Control: 19802014. Management Accounting Research, 31(2), 4562.

Owoyemi, O., dan Ekwoaba, J. (2014). Organizational Culture: A Tool for Management to Control, Motivate, and Performance Enhacement. American Journal of Business and Management, 3(3), 168-177.

Pedroche, M. S. C., Rubio, L., Rodríguez, J. M., dan Almeida, M. D. M. A. (2017). Causal Relationships between Organisational Learning and Performance in the Spanish Hotel Industry: the Managers' Perception in Times of Economic 
Crisis. International Journal of Innovation and Learning, 21(3), 274-298.

Reginato, L., dan Guerreiro, R. (2013). Relationships between Environment, Culture, and Management Control Systems. International Journal of Organizational Analysis, 21(2), 219-240.

Robbins, S. P., dan Coulter, M. (2016). Manajemen [Terjemahan] (Edisi ke-13). Jakarta: Penerbit Erlangga.

Santiago, M. D. R. R., Medina, P. S. S., dan Pichardo, R. D. (2017). Eco-Innovation and Organizational Culture in The Hotel Industry. International Journal of Hospitality Management, 65, 71-80.

Schein, E. H. (2004). Organizational Culture and Leadership. San Fransisco: Jossey-Bass.

Sumarsono, D. (2014). Dahsyatnya Bisnis Hotel di Indonesia. Jakarta: PT Gramedia Pustaka Utama.

Syamsi. (2019, Agustus 14). Wisman Menurun, Begini Okupansi Hotel di Makasar. Portalmakassar.com, p. 1.

Tseng, S. M. (2010). The Correlation between Organizational Culture and Knowledge Conversion on Corporate Performance. Journal of Knowledge Management, 14(2), 269-284.

Woods, R. C. (1989). More Alike than Different: The Culture of the Restaurant Industry. The Cornell Hotel and Restaurant Administration Quarterly, 30(2), 82-98.

Zheng, W., Yang, B., dan McLean, G. N. (2010). Linking Organization Culture, Structure, Strategy, and Organizational Effectiveness: Mediating Role of Knowledge Management. Journal of Business Research, 63(7), 763-771.

Zuriana, C., Jamil, M., dan Mohamed, R. (2013). The Effect of Management Control System on Performance Measurement System at Small Medium Hotel in Malaysia. International Journal of Trade, Economics and Finance, 4(4), 202-208. 